CZASOPISMO INŻYNIERII LĄDOWEJ, ŚRODOWISKA I ARCHITEKTURY JOURNAL OF CIVIL ENGINEERING, ENVIRONMENT AND ARCHITECTURE JCEEA, t. XXXIII, z. 63 (2/II/16), kwiecień-czerwiec 2016, s. 21-38

\author{
Marek BOGACKI ${ }^{1}$ \\ Mateusz RZESZUTEK ${ }^{2}$ \\ Kamil HEBA ${ }^{3}$
}

\title{
MODELOWANIE DYSPERSJI ZANIECZYSZCZEŃ POWIETRZA W KANIONIE ULICZNYM NA PRZYKŁADZIE ALEI KRASIŃSKIEGO W KRAKOWIE
}

\begin{abstract}
W artykule przedstawiono ocenę wpływu na jakość powietrza emisji z transportu drogowego w kanionie ulicznym aleja Krasińskiego w Krakowie ze względu na poziomy stężeń dwutlenku azotu $\left(\mathrm{NO}_{2}\right)$ oraz pyłu zawieszonego $\mathrm{PM}_{10}$ i $\mathrm{PM}_{2.5}$. Ocenę przeprowadzono na podstawie wyników obliczeń z zastosowaniem modelu OSPM (Operational Street Pollution Model). Wielkość emisji zanieczyszczeń do powietrza $\mathrm{z}$ transportu drogowego oszacowano zgodnie z metodyką CORINAIR opracowaną przez Europejską Agencję Ochrony Srodowiska. W procesie obliczeniowym wykorzystano dane pochodzące ze stacji meteorologicznej zlokalizowanej w rejonie Akademii Górniczo-Hutniczej w Krakowie, a tło zanieczyszczeń pozyskano ze stacji monitoringu jakości powietrza zlokalizowanej przy ul. Bujaka w Krakowie. W pracy zawarto również porównanie wyników modelowania ze stężeniami mierzonymi na stacji monitoringu jakości powietrza zlokalizowanej w kanionie ulicznym alei Krasińskiego. Wyniki analiz potwierdziły znaczącą rolę emisji z transportu drogowego w kształtowaniu wysokich poziomów stężeń $\mathrm{NO}_{2}$ oraz pyłu zawieszonego $\mathrm{PM}_{10}$ i $\mathrm{PM}_{2.5}$ w powietrzu kanionu ulicznego. Stwierdzono, że wpływ transportu drogowego na poziom stężeń $\mathrm{NO}_{2}, \mathrm{PM}_{10}$ i $\mathrm{PM}_{2.5} \mathrm{w}$ powietrzu zmienia się sezonowo, a największy wpływ obserwowany jest latem. W okresie tym udział emisji z transportu drogowego w kształtowaniu poziomów stężeń $\mathrm{NO}_{2}$, $\mathrm{PM}_{10}$ i $\mathrm{PM}_{2.5}$ w powietrzu w kanionie ulicznym wynosi odpowiednio 62,35 i $31 \%$.
\end{abstract}

Słowa kluczowe: emisja, transport drogowy, ocena wpływu na jakość powietrza, kanion uliczny, modelowanie dyspersji zanieczyszczeń powietrza, model OSPM

\footnotetext{
${ }^{1}$ Autor do korespondencji / corresponding author: Marek Bogacki, AGH Akademia GórniczoHutnicza, Wydział Geodezji Górniczej i Inżynierii Środowiska, Katedra Kształtowania i Ochrony Środowiska, al. A. Mickiewicza 30, 30-059 Kraków, tel. + 4812 6174503, e-mail: bogacki@agh.edu.pl

2 Mateusz Rzeszutek, AGH Akademia Górniczo-Hutnicza, e-mail: rzeszut@agh.edu.pl

${ }^{3}$ Kamil Heba, AGH Akademia Górniczo-Hutnicza, e-mail: kamil.heba@o2.pl
} 


\section{Wstęp}

Na obszarze strefy „Aglomeracja Krakowska” od wielu lat występują przekroczenia średniorocznych i średniodobowych poziomów dopuszczalnych stężeń dwutlenku azotu $\left(\mathrm{NO}_{2}\right)$, pyłu zawieszonego $\left(\mathrm{PM}_{10}\right)$ i benzo(a)pirenu (b(a)p). $\mathrm{W}$ związku $\mathrm{z}$ tym strefa ta zaliczana jest do klasy $\mathrm{C}$ oceny jakości powietrza atmosferycznego [1]. Wysokie stężenia $\mathrm{NO}_{2}$ i $\mathrm{PM}_{10}$ obserwowane są również na stacji monitoringu jakości powietrza zlokalizowanej w kanionie ulicznym alei Krasińskiego w Krakowie. Częstość przekroczeń poziomów średniodobowych stężenia $\mathrm{PM}_{10}$ w kanionie ulicznym alei Krasińskiego w latach 2005-2015 wynosiła od 158 do 262 dni i była dwukrotnie wyższa niż rejestrowana w tym samym okresie na stacji tła miejskiego (ul. Bujaka w Krakowie), gdzie mieściła się w przedziale od 100 do 157 dni [2]. Ostatni raport Europejskiej Agencji Ochrony Środowiska (EEA) wskazuje, że podobna sytuacja występuje w wielu większych miastach Europy. Rejestrowane w tych miastach przekroczenia poziomów dopuszczalnych stężeń średniodobowych $\mathrm{PM}_{10}$ i średniorocznych $\mathrm{NO}_{2}$ występują najczęściej na stacjach mierzących oddziaływanie transportu drogowego, ulokowanych w kanionach ulicznych [3].

Wpływ transportu drogowego na jakość powietrza w kanionie ulicznym jest większy niż w innych rejonach miasta, ponieważ występują w nim gorsze warunki dyspersji wyemitowanych do powietrza zanieczyszczeń (słaba cyrkulacja i wentylacja powietrza) [4]. Wiatry równoległe do osi drogi powodują nakładanie się smug zanieczyszczeń wyemitowanych w kanionie, co potęguje oddziaływania transportu na stan jakości powietrza. W tym specyficznym obszarze o jakości powietrza w dużej mierze decydują parametry meteorologiczne [5-7] oraz geometria kanionu, turbulencje mechaniczne oraz efekty termiczne ogrzewania kanionu [8]. Złożoność czynników determinujących proces dyspersji zanieczyszczeń powietrza w kanionie ulicznym jest bardzo duża, stąd do obliczeń poziomów stężeń w powietrzu stosuje się z reguły wyspecjalizowane narzędzia przystosowane wyłącznie do tego typu obszarów $[9,10]$. Wyróżnić można dwie zasadnicze grupy modeli dyspersji zanieczyszczeń powietrza stosowane dla kanionów ulicznych. Pierwszą grupę stanowią parametryczne (operacyjne) modele dyspersji w tym empiryczne i pół-empiryczne. Przedstawicielami parametrycznych modeli są CALINE3, CALINE4, STREET, CPBM, ADMS, OSPM i AEOLIUS [10]. Drugą grupę stanowią numeryczne techniki modelowania, do których zaliczamy modele CFD [11], często stosowane obok modeli operacyjnych w obliczeniach dyspersji zanieczyszczeń powietrza w kanionach ulicznych [12].

Dotychczasowe obliczenia modelowe dyspersji zanieczyszczeń emitowanych $\mathrm{z}$ transportu drogowego na terenie Krakowa prowadzone były przy zastosowaniu modeli CALINE3, CALINE4 [13-15]. Zastosowanie tego narzędzia w środowisku miejskim, dla obszaru kanionu ulicznego budzi pewne wątpliwości, gdyż gaussowska formuła modelu CALINE4 pozwala wykonywać oblicze- 
nia w kanionie ulicznym tylko dla wiatrów równoległych do osi drogi [16]. Badania walidujące ten model wykazały, że jest on nieodpowiedni do symulacji dyspersji zanieczyszczeń w kanionie ulicznym w przypadku wiatrów o kierunku odchylonym względem osi kanionu o więcej niż \pm 30 stopni. Do obliczeń propagacji zanieczyszczeń w kanionach ulicznych zdecydowanie lepszym rozwiązaniem jest zastosowanie innych modeli np.: STREET, CPBM, OSPM [17]. Badania porównawcze modeli dyspersji zanieczyszczeń powietrza pochodzących z transportu drogowego, opracowane na podstawie dwóch eksperymentów polowych wskazują, że istnieją obecnie znacznie lepsze modele niż CALINE4. Należą do nich: R-LINE, ADMS, AERMOD [18].

$\mathrm{W}$ pracy przedstawiono wyniki obliczeń modelowych wpływu emisji $\mathrm{z}$ transportu drogowego na poziom stężeń $\mathrm{w}$ powietrzu kanionu ulicznego takich zanieczyszczeń jak: $\mathrm{NO}, \mathrm{NO}_{2}, \mathrm{NO}_{\mathrm{x}}$ oraz $\mathrm{PM}_{10}$ i $\mathrm{PM}_{2,5}$. Obliczenia dyspersji zanieczyszczeń powietrza przeprowadzono za pomocą modelu OSPM (Operational Street Pollution Model) opracowanego w Narodowym Instytucie Badań Środowiska w Dani $[19,20]$. Model ten jest dedykowany do wykonywania obliczeń dyspersji zanieczyszczeń w kanionach ulicznych. Należy on do grupy modeli operacyjnych, charakteryzuje się wysoką reprezentatywnością uzyskiwanych wyników, niskimi kosztami obliczeniowymi oraz relatywnie niskimi wymaganiami w zakresie niezbędnych danych wejściowych [20-23]. $\mathrm{W}$ pracy obliczenia modelowe wykonano wyłącznie dla kanionu ulicznego alei Krasińskiego, wewnątrz którego prowadzone są również pomiary stężeń wybranych zanieczyszczeń powietrza, co pozwoliło zweryfikować uzyskiwane wyniki obliczeń.

\section{Charakterystyka obiektu badań}

Obiektem badań był odcinek drogi alei Krasińskiego położony w Krakowie pomiędzy skrzyżowaniami z aleją Focha i ul. Kościuszki. Składa się on z dwóch jezdni rozdzielonych szerokim pasem zieleni. Każda z jezdni na badanym odcinku składa się z 3 pasów ruchu. Dwa pasy wewnętrzne przeznaczone są dla wszystkich rodzajów pojazdów, a trzeci pas ruchu zarezerwowany jest dla autobusów, taksówek, policji oraz prawoskrętu. Analizowany obszar jest przykładem typowego kanionu ulicznego o stosunku wysokości zabudowy $(\mathrm{H})$ do szerokości kanionu $(\mathrm{B})$ na poziomie $0,42(\mathrm{H} \approx 20 \mathrm{~m}, \mathrm{~B} \approx 48 \mathrm{~m})$ i orientacji drogi względem północy $-159^{\circ}$. Rozpatrywany odcinek drogi jest elementem II obwodnicy Krakowa, która charakteryzuje się jedną z najwyższych przepustowości pojazdów w Krakowie oraz nietypową zmiennością dobową natężenia ruchu. Nie występują na niej wyraźne szczyty poranne i popołudniowe natężenia ruchu. Okres od godziny $8^{00}$ do $15^{00}$ charakteryzuje się równomiernym natężeniem ruchu. Zależność tę przedstawiono na rysunku 1. Zawiera on godzinowe wartości natężenia ruchu dla alei Mickiewicza stanowiącej przedłużenie alei Krasińskiego uśrednione dla dni roboczych (dane z 2012 r.). Prowadzone w Krakowie badania do- 
tyczące natężenia ruchu na różnych drogach wskazują, że zmienność dobowa natężenia ruchu jest podobna dla wszystkich dni roboczych (poniedziałek - piątek). Soboty i niedziele należy traktować jako osobne okresy, charakteryzujące się odmiennym profilem dobowych zmian natężenia ruchu [24]. Średnie godzinowe natężenie ruchu uśrednione dla okresu doby, charakterystyczne dla II obwodnicy Krakowa wynosiło w roku 2012 dla dni roboczych oraz sobót i niedziel odpowiednio 1780,1670 i 1380 poj. $\mathrm{h}^{-1}$.

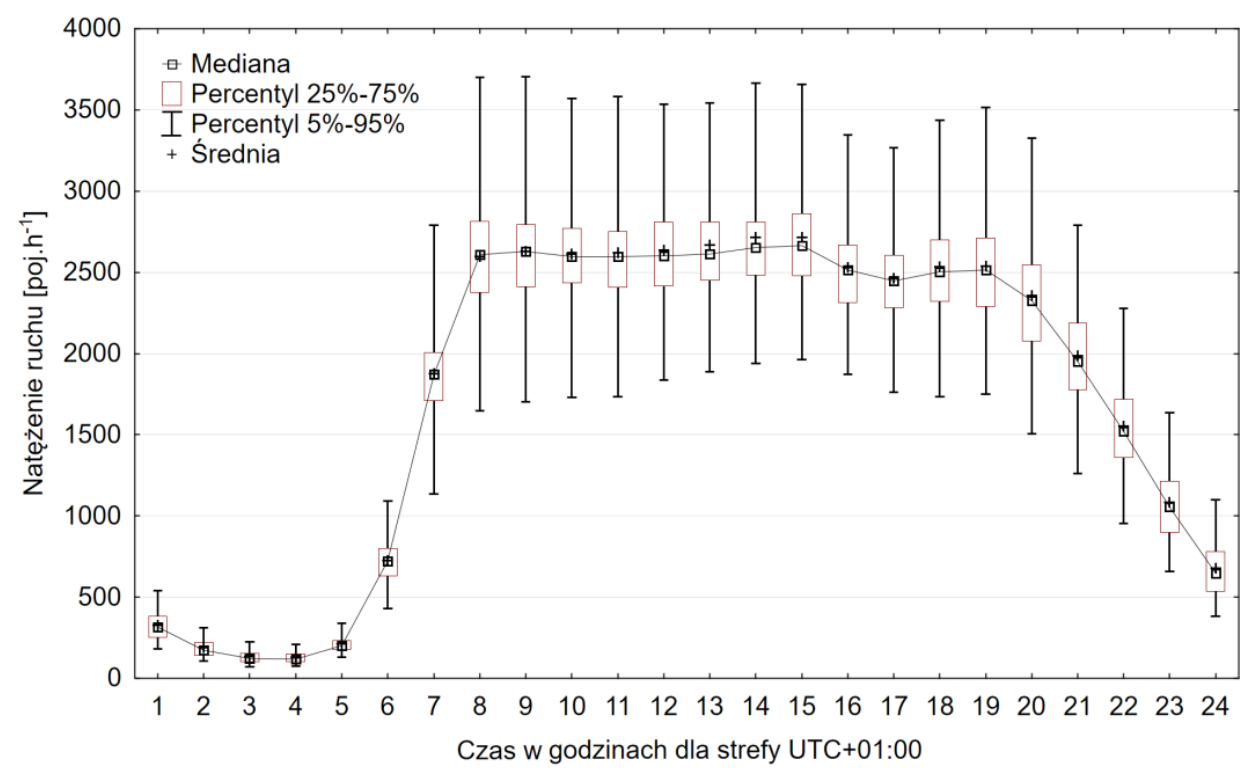

Rys. 1. Dobowy rozkład godzinowego natężenia ruchu w dni robocze na alei Mickiewicza w Krakowie w 2012 roku

Fig. 1. Daily distribution of hourly averaged traffic volume values during working days for the Mickiewicza alley in Krakow in 2012

Okresowo prowadzone przez Zarząd Infrastruktury Komunalnej i Transportu w Krakowie (ZIKiT) na tym odcinku drogi badania struktury ruchu wskazują, że około $85 \%$ poruszających się po niej pojazdów stanowią samochody osobowe, ok. 6\% samochody dostawcze i tyle samo środki transportu publicznego (mikrobusy i autobusy). Samochody ciężarowe i motocykle stanowią najmniej liczną grupę pojazdów (ok. 2\%). Ostatnie wyniki analiz głównego urzędu statystycznego dla gminy Kraków wskazują, że na przestrzeni ostatniego 10-lecia nastąpił silny wzrost liczby pojazdów osobowych charakteryzujących się dużą masą całkowitą, większą niż $1900 \mathrm{~kg}$ (11-krotny wzrost w stosunku do roku 2003), oraz samochodów o pojemności większej niż $2000 \mathrm{~cm}^{3}$ (2-krotny wzrost w stosunku do roku 2003). Zjawisko to jest niepokojące, ponieważ mimo od- 
mładzającej się floty pojazdów spełniającej wyższe normy jakości spalin, emisja $\mathrm{z}$ transportu drogowego może nie ulec zmniejszeniu. $\mathrm{Z}$ powodu istotnego wzrostu liczby pojazdów oraz zwiększenia udziałów samochodów o dużej masie całkowitej i dużej pojemności silnika może nastąpić wzrost emisji zanieczyszczeń do powietrza $\mathrm{z}$ transportu drogowego [25].

\section{Charakterystyka modelu OSPM oraz metodyka obliczeń}

Obliczenia poziomów stężeń zanieczyszczeń gazowych $\left(\mathrm{NO}, \mathrm{NO}_{2}, \mathrm{NO}_{\mathrm{x}}\right)$ i pyłowych $\mathrm{PM}_{10}$ i $\mathrm{PM}_{2,5}$ w kanionie alei Krasińskiego wykonano operacyjnym modelem OSPM (Operational Street Pollution Model). Model ten ma charakter hybrydowy. Oparty jest na trzech komplementarnych formułach obliczeniowych: a) gaussowskim modelu smugi odpowiedzialnym za transport zanieczyszczeń od źródła do receptora, b) modelu pudełkowym (box model) opisującym recyrkulację zanieczyszczonego powietrza $\mathrm{w}$ kanionie ulicznym, c) mechanizmie odzwierciedlającym poziom tła zanieczyszczeń powietrza $\mathrm{w}$ oparciu o dane ze stacji monitorujących tło miejskie lub regionalne zanieczyszczeń powietrza $[19,20]$.

Przedstawiony na rysunku 2 schemat modelu OSPM wskazuje, że model ten składa się z 4 zasadniczych modułów odpowiedzialnych za ustawienia wejściowe modelu (moduły: emisji, konfiguracji drogi, danych meteorologicznych i tła zanieczyszczeń powietrza). W obliczeniach wykorzystywano wszystkie wyżej wymienione moduły. Obliczenia emisji zanieczyszczeń z transportu drogowego wymagały określenia natężenia i struktury ruchu pojazdów poruszających się w kanionie ulicznym. Dane te opracowano na podstawie ciągłych oraz okresowych danych pomiarowych dotyczących natężenia i struktury ruchu. Dane dotyczące struktury ruchu ograniczone były do 7 kategorii pojazdów, które były monitorowane przez Zarząd Infrastruktury Komunalnej i Transportu w Krakowie w obrębie II obwodnicy Krakowa. Szczegółową strukturę pojazdów opracowano na podstawie statystyk udostępnionych przez Wydział Ewidencji Pojazdów i Kierowców Urzędu Miasta Krakowa. Na podstawie wyżej opisanych danych wykonano obliczenia emisji zanieczyszczeń do powietrza $\mathrm{z}$ transportu drogowego z zastosowaniem modułu szacowania wielkości emisji WinOSPM. Moduł ten szacuje emisję na podstawie metodyki zawartej w przewodniku do krajowych inwentaryzacji emisji Europejskiej Agencji Ochrony Środowiska (EEA) [26].

Dane meteorologiczne wykorzystane w obliczeniach pochodziły ze stacji pomiarowej zlokalizowanej na wysokości $20 \mathrm{~m}$ n.p.t. (dach budynku należącego do Wydziału Fizyki i Informatyki Stosowanej AGH), położonej w odległości ok. $1,5 \mathrm{~km}$ od badanego kanionu. Punkt ten spełniał wymagania stawiane przez model $\mathrm{w}$ zakresie miejsca pomiarów prędkości i kierunku wiatru. Wysokość warstwy mieszania wyznaczono za pomocą modelu CALMET [27]. Natomiast informacje o poziomie tła zanieczyszczeń powietrza z rozdzielczością godzino- 
wą pochodziły ze stacji monitoringu jakości powietrza tła miejskiego w Krakowie, zlokalizowanej przy ul. Bujaka (os. Kurdwanów).

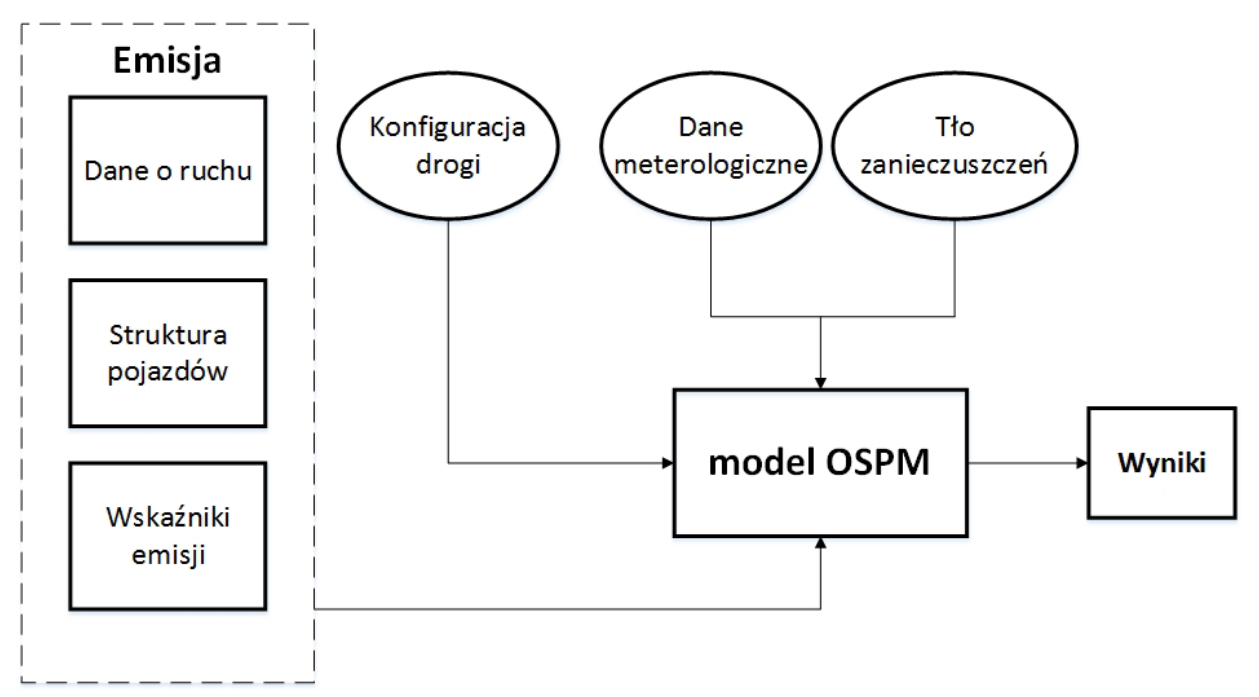

Rys. 2. Schemat modelu dyspersji zanieczyszczeń powietrza w kanionie ulicznym (OSPM)

Fig. 2. Schematic representation of air pollutant dispersion model in a street canyon (OSPM)

Obliczenia dyspersji zanieczyszczeń powietrza w kanionie ulicznym przeprowadzono dla okresu jednego roku kalendarzowego tj. 2012 r. Model zasilany jest dużą ilością danych pomiarowych w formie szeregów czasowych, które z powodów technicznych (np. usterki urządzeń pomiarowych) mogą być niekompletne. W takim przypadku model OSPM pomija brakujące okresy w obliczeniach (dane nie są sztucznie uzupełniane).

W pracy przeprowadzono porównanie wyników modelowania z wartościami stężeń rejestrowanymi na stacji jakości powietrza położonej w analizowanym kanionie ulicznym. Analizę porównawczą wykonano względem wartości stężeń średnich miesięcznych oraz uśrednionych dla okresu letniego i zimowego (grzewczego). Porównanie wyników przeprowadzono wyłącznie względem istniejących par danych (obserwacje-modelowanie).

\section{Wyniki i dyskusja}

\subsection{Wyniki obliczeń poziomów stężeń zanieczyszczeń powietrza}

W tabeli 1 zestawiono wyniki modelowania dyspersji zanieczyszczeń w postaci wartości średnich miesięcznych i maksymalnych 1-godzinnych stężeń 
w powietrzu wybranych zanieczyszczeń gazowych i pyłowych powodowanych przez transport drogowy w kanionie ulicznym aleja Krasińskiego w 2012 roku.

Tabela 1. Obliczone średnie miesięczne i maksymalne 1-godzinne stężenia wybranych zanieczyszczeń powietrza $\mathrm{w} \mu \mathrm{g} \mathrm{m}^{-3}$ powodowane przez transport drogowy $\mathrm{w}$ kanionie ulicznym aleja Krasińskiego

Table 1. Calculated monthly averaged and 1-hour maximum concentrations of selected air pollutants expressed in $\mu \mathrm{g} \mathrm{m}^{-3}$ originating from the road transport in the Krasinskiego alley street canyon

\begin{tabular}{|c|c|c|c|c|c|c|c|c|c|c|}
\hline \multirow{2}{*}{ Miesiąc } & \multicolumn{2}{|c|}{ NO } & \multicolumn{2}{c|}{ NO $_{\mathbf{2}}$} & \multicolumn{2}{c|}{ NO $_{\mathbf{x}}$} & \multicolumn{2}{c|}{$\mathbf{P M}_{\mathbf{1 0}}$} & \multicolumn{2}{c|}{$\mathbf{P M}_{\mathbf{2 , 5}}$} \\
\cline { 2 - 11 } & śr. & maks. & śr. & maks. & śr. & maks. & śr. & maks. & śr. & maks. \\
\hline I & 44,2 & 125 & 29,0 & 74 & 96,7 & 232 & 8,6 & 18 & 4,5 & 10 \\
\hline II & 46,9 & 110 & 34,6 & 82 & 106,3 & 207 & 11,5 & 18 & 6,1 & 10 \\
\hline III & 57,9 & 138 & 36,6 & 109 & 121,1 & 253 & 8,3 & 16 & 4,3 & 9 \\
\hline IV & 55,1 & 126 & 43,3 & 98 & 128,6 & 243 & 11,3 & 22 & 5,8 & 12 \\
\hline V & 56,2 & 125 & 46,0 & 100 & 132,0 & 235 & 11,2 & 22 & 5,6 & 12 \\
\hline VI & 53,0 & 116 & 49,6 & 112 & 131,6 & 220 & 9,9 & 21 & 5,2 & 12 \\
\hline VII & 53,1 & 116 & 49,6 & 124 & 131,5 & 233 & 11,0 & 20 & 5,6 & 10 \\
\hline VIII & 54,6 & 118 & 47,9 & 126 & 136,3 & 250 & 11,8 & 22 & 6,1 & 12 \\
\hline IX & 55,2 & 132 & 40,2 & 111 & 128,0 & 256 & 12,5 & 26 & 7,1 & 15 \\
\hline X & 52,2 & 122 & 33,3 & 74 & 115,7 & 230 & 11,5 & 24 & 6,4 & 14 \\
\hline XI & 76,7 & 143 & 35,5 & 84 & 153,6 & 265 & 13,8 & 26 & 7,4 & 15 \\
\hline XII & 73,1 & 143 & 33,7 & 71 & 145,5 & 272 & 13,5 & 28 & 7,1 & 15 \\
\hline
\end{tabular}

Wartości średniomiesięczne stężeń $\mathrm{NO}_{2}$ w powietrzu, powodowane przez transport drogowy w kanionie ulicznym w miesiącach chłodniejszych kształtują się na poziomie $30-35 \mu \mathrm{g} \mathrm{m}^{-3}$, a w wiosennych i letnich osiągają prawie $50 \mu \mathrm{g} \mathrm{m}^{-3}$, czyli są wyższe niż średnioroczny poziom dopuszczalny dwutlenku azotu w powietrzu atmosferycznym, który wynosi $40 \mu \mathrm{g} \mathrm{m}^{-3}$ [28]. Podobną sezonową zależność wykazują również maksymalne 1-godzinne stężenia $\mathrm{NO}_{2}$, gdzie zdecydowanie najwyższe wartości występują w okresie letnim. Wyemitowane z pojazdów samochodowych tlenki azotu w formie tlenku azotu (NO) pod wpływem między innymi ozonu $\left(\mathrm{O}_{3}\right)$ ulegają konwersji do $\mathrm{NO}_{2}$ [20]. Wyższe w okresie letnim stężenia dwutlenku azotu w porównaniu do okresu chłodnego są wynikiem innego chemizmu atmosfery w obu okresach, a tym samym innego udziału $\mathrm{w}$ atmosferze substancji śladowych, odpowiedzialnych między innymi za tworzenie się ozonu. Zarejestrowany na stacji tła miejskiego w Krakowie przy ul. Bujaka średniomiesięczny poziom stężeń ozonu w okresie zimowym 
wynosił 35-50 $\mu \mathrm{g} \mathrm{m}^{-3}$, a w letnim $60-80 \mu \mathrm{g} \mathrm{m}^{-3}$ [2], co potwierdza silny związek pomiędzy stężeniami $\mathrm{NO}_{2} \mathrm{i} \mathrm{O}_{3} \mathrm{w}$ powietrzu. Stosunek średnich miesięcznych stężeń $\mathrm{NO}$ do $\mathrm{NO}_{2}$ zestawionych w tabeli 1 jest w każdym przypadku wyższy od 1. Jest to sytuacja charakterystyczna dla obszaru kanionu ulicznego, gdzie w wyniku procesu spalania paliw w silnikach pojazdów emitowany jest do powietrza głównie tlenek azotu [3]. W okresie letnim stosunek ten ulega zmniejszeniu, co wynika z intensyfikacji procesu konwersji $\mathrm{NO}$ do $\mathrm{NO}_{2}$ na drodze reakcji fotochemicznych.

Obliczona wartość stężenia średniorocznego $\mathrm{NO}_{2}$ powodowana przez emisję z transportu drogowego w roku 2012 wyniosła $39,9 \mu \mathrm{g} \mathrm{m}^{-3}$, co oznacza, że sam transport drogowy w analizowanym kanionie ulicznym powoduje stężenia na poziomie średniorocznego poziomu dopuszczalnego. Informacja ta jest niezwykle ważna w kontekście działań zmierzających do poprawy jakości powietrza, gdyż umniejszenie roli komunikacji w programach naprawczych może doprowadzić do nieosiągnięcia zamierzonych celów. Wyniki modelowania wskazują, że 1-godzinny poziom dopuszczalny stężenia $\mathrm{NO}_{2}$ wynoszący $200 \mu \mathrm{g} \mathrm{m}^{-3}$ nie został przekroczony [28]. W związku z powyższym można stwierdzić, że 1-godzinny standard jakości powietrza dla $\mathrm{NO}_{2}$, jest mniej rygorystyczny w porównaniu do średniorocznego poziomu stężenia dopuszczalnego. Wspomniane tendencje występujące w Krakowie są charakterystyczne również dla obszarów miejskich w Europie, na co wskazuje ostatni raport EEA w sprawie jakości powietrza [3].

Zestawione $\mathrm{w}$ tabeli 1 wyniki obliczeń stężeń średniomiesięcznych $\mathrm{PM}_{10}$ i $\mathrm{PM}_{2.5} \mathrm{~W}$ powietrzu wynikające $\mathrm{z}$ emisji $\mathrm{z}$ transportu drogowego nie powodują przekroczeń dopuszczalnego stężenia średniorocznego określonego w rozporządzeniu Ministra Środowiska z dnia 24 sierpnia 2012 r. w sprawie poziomów niektórych substancji w powietrzu [28]. Wahania (niewielkie) wartości średniomiesięcznych stężeń zanieczyszczeń pyłowych (tabela 1), są determinowane głównie zmiennym w poszczególnych miesiącach natężeniem ruchu [13] oraz zmianami warunków meteorologicznych [24]. Obliczone maksymalne 1-godzinne stężenia $\mathrm{PM}_{10}$ i $\mathrm{PM}_{2.5} \mathrm{~W}$ powietrzu występują na niskim poziomie wynoszącym ok. 16-28 $\mu \mathrm{g} \mathrm{m}^{-3}$, co stanowi zaledwie kilka procent maksymalnych stężeń $\mathrm{PM}_{10}$ i $\mathrm{PM}_{2,5}$ obserwowanych na stacji pomiarowej. Prawdopodobnie dodatkowy, a zarazem istotny wkład w mierzone stężenia pyłu $\mathrm{PM}_{10}$ i $\mathrm{PM}_{2.5}$ może mieć emisja wtórna pyłu unoszonego z nawierzchni drogi, nie uwzględniona w niniejszej pracy [29]. Wyniki obliczeń wskazują, że emisja z silników samochodowych w niewielkim stopniu przyczynia się do występowania epizodów bardzo wysokich stężeń pyłów zawieszonych.

\subsection{Porównanie wyników modelowania z obserwacjami}

W tabeli 2 zamieszczono wartości średnich zamodelowanych i obserwowanych stężeń w okresie zimowym i letnim dla takich substancji jak: $\mathrm{NO}, \mathrm{NO}_{2}$, 
$\mathrm{NO}_{\mathrm{x}}, \mathrm{PM}_{10}$ i $\mathrm{PM}_{2,5}$. Dla zilustrowania skuteczności prognostycznej modelu obliczono dodatkowo iloraz odpowiednich wartości zamodelowanych i obserwowanych stężeń. Uzyskane wyniki wskazują, że model OSPM gorzej odzwierciedla stężenia obserwowane w okresie zimowym, gdzie tło miejskie określone na podstawie danych ze stacji monitoringu jakości powietrza może nie być do końca reprezentatywne. $\mathrm{W}$ okresie zimowym poza dobrym odwzorowaniem stężenia $\mathrm{NO}_{2} \mathrm{~W}$ powietrzu mamy do czynienia $\mathrm{z}$ niedoszacowaniem wartości średnich stężeń pozostałych analizowanych substancji. Pomijając sam błąd szacowania emisji, prawdopodobnie w okresie tym stacja przy alei Krasińskiego znajdowała się pod silnym wpływem innych, nie uwzględnionych w obliczeniach źródeł emisji, np. z sektora energetyki zawodowej, przemysłu lub sektora komunalnobytowego.

Tabela 2. Zestawianie średnich stężeń zamodelowanych $\left(\mathrm{S}_{\text {mod. }}\right)$ i obserwowanych $\mathrm{w}$ kanionie ulicznym aleja Krasińskiego $\left(\mathrm{S}_{\mathrm{obs}}\right)$ oraz stosunku ww. wartości $\left(\mathrm{S}_{\mathrm{mod}} / \mathrm{S}_{\mathrm{obs}}\right)$ z podziałem na sezon zimowy i letni

Table 2. Comparison of the average modelled $\left(\mathrm{S}_{\mathrm{mod}}\right)$ and observed concentrations in the Krasinski alley street canyon $\left(\mathrm{S}_{\mathrm{obs}}\right)$ and their ratios $\left(\mathrm{S}_{\mathrm{mod}} / \mathrm{S}_{\mathrm{obs}}\right)$ with seasonal division (summer and winter)

\begin{tabular}{|c|c|c|c|c|c|c|c|c|}
\hline \multirow{2}{*}{$\begin{array}{c}\text { Sub- } \\
\text { stancja }\end{array}$} & \multicolumn{4}{|c|}{ Sezon zimowy } & \multicolumn{4}{c|}{ Sezon letni } \\
\cline { 2 - 9 } & $\mathbf{n}$ & $\mathbf{S}_{\mathbf{m o d} .}$ & $\mathbf{S}_{\text {obs. }}$ & $\mathbf{S}_{\text {mod. }} / \mathbf{S}_{\text {obs. }}$ & $\mathbf{n}$ & $\mathbf{S}_{\text {mod. }}$ & $\mathbf{S}_{\text {obs. }}$ & $\mathbf{S}_{\mathbf{m o d}} / \mathbf{S}_{\text {obs. }}$ \\
\cline { 2 - 9 } & - & {$\left[\boldsymbol{\mu g ~ m}^{-3}\right]$} & {$\left[\boldsymbol{\mu} \mathbf{~ m}^{-3}\right]$} & - & - & {$\left[\boldsymbol{\mu g} \mathbf{~ m}^{-3}\right]$} & {$\left[\boldsymbol{\mu g} \mathbf{~ m}^{-3}\right]$} & - \\
\hline $\mathbf{N O}$ & 3278 & 93,7 & 130,9 & 0,72 & 3137 & 67,6 & 82,6 & 0,82 \\
\hline $\mathbf{N O}_{\mathbf{2}}$ & 3474 & 69,5 & 67,0 & 1,04 & 3304 & 74,7 & 77,0 & 0,97 \\
\hline $\mathbf{N O}_{\mathbf{x}}$ & 3404 & 213,2 & 264,7 & 0,81 & 3330 & 181,0 & 203,2 & 0,89 \\
\hline $\mathbf{P M}_{\mathbf{1 0}}$ & 2251 & 74,5 & 97,3 & 0,77 & 3217 & 39,3 & 43,9 & 0,89 \\
\hline $\mathbf{P M}_{\mathbf{2 . 5}}$ & 2431 & 49,8 & 69,6 & 0,71 & 3433 & 22,6 & 27,1 & 0,84 \\
\hline
\end{tabular}

Na rysunku 3 przedstawiono wartości mediany i średniej rocznej wraz z percentylem $25 \%-75 \%$ (ramka) oraz 5\%-95\% (wąsy) zamodelowanych stężeń 1-godzinnych porównane ze stężeniami zmierzonymi na stacji monitoringu jakości powietrza zlokalizowanej przy alei Krasińskiego.

Model OSPM bardzo dobrze odzwierciedla wartości stężeń średnich 1-godzinnych $\mathrm{NO}_{2}$, jednak zarówno w przypadku $\mathrm{NO}$ i $\mathrm{NO}_{\mathrm{x}}$ stężenia zamodelowane są niższe od obserwowanych. Może to wynikać z uproszczonego schematu konwersji $\mathrm{NO}$ do $\mathrm{NO}_{2}$ zastosowanego w modelu OSPM. Schemat ten oparty został na założeniu istnienia równowagi fotochemicznej pomiędzy $\mathrm{NO}-\mathrm{NO}_{2}-\mathrm{O}_{3}$. Założenie to sprawdza się stosunkowo dobrze w sytuacji modelowania przemian fotochemicznych dla krótkich przedziałów czasowych (np. do 1-godziny) w dobrze wymieszanej atmosferze, stąd duża część modeli dyspersji implementuje ten mechanizm. Rozdzielczość czasowa 1-godzinna w jakiej były wykony- 
wane obliczenia modelowe oraz obszar kanionu, w którym występują turbulencje mechaniczne intensyfikujące mieszanie zanieczyszczeń, teoretycznie powinny gwarantować uzyskiwanie wysokich skuteczności prognostycznych modelu. Przeprowadzona walidacja wyników obliczeń w zakresie stężeń tlenków azotu w powietrzu wskazuje jednak na istnienie innych czynników, które w badanej przestrzeni wpływają na zmniejszenie skuteczności prognostycznej modelu w zakresie stężeń $\mathrm{NO}$ i $\mathrm{NO}_{\mathrm{x}}$. Czynnikami tymi mogą być zarówno nie uwzględnione $\mathrm{w}$ procesie modelowania substancje śladowe znajdujące się w rzeczywistej atmosferze (np. węglowodory, które w istotny sposób podnoszą potencjał fotochemiczny powietrza), czy niepewność danych emisyjnych, która obejmuje nie tylko niepewność wynikającą z szacowania natężenia ruchu, jak również struktury pojazdów poruszających się w analizowanym kanionie.

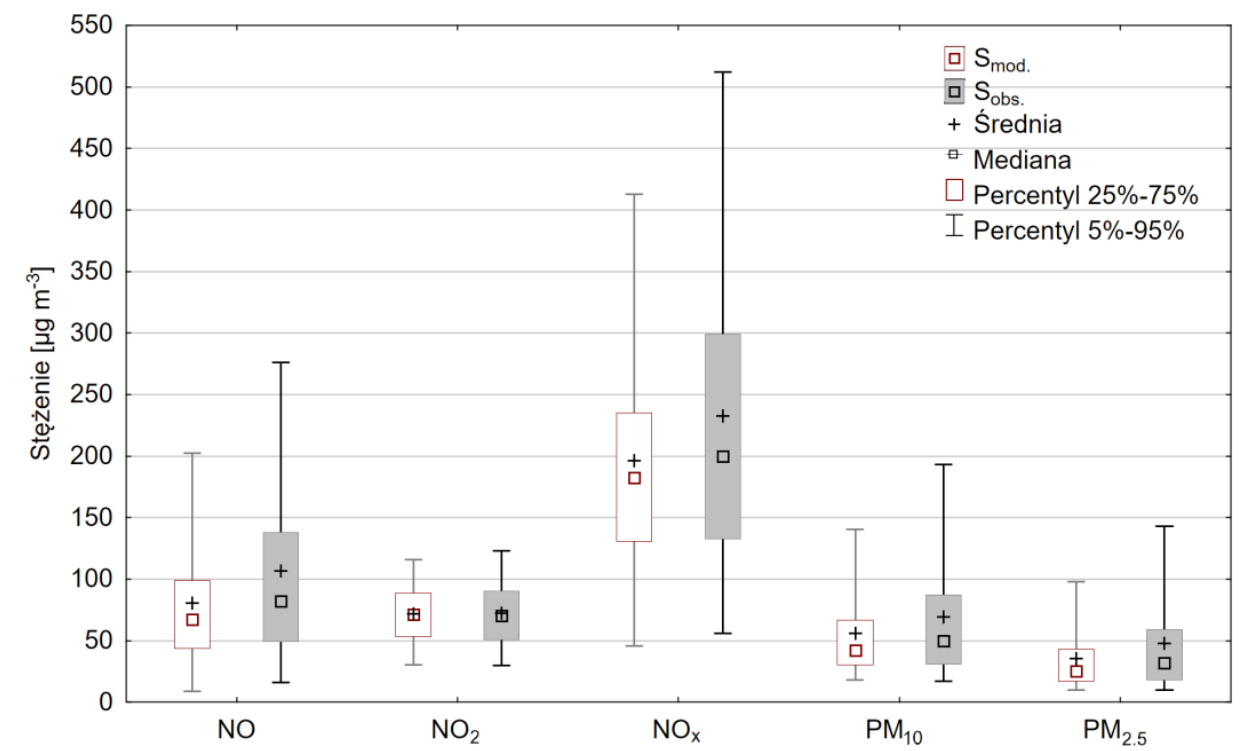

Rys. 3. Porównanie wyników zamodelowanych stężeń $\left(\mathrm{S}_{\text {mod. }}\right)$ z wartościami stężeń $\left(\mathrm{S}_{\text {obs. }}\right)$ zmierzonych na stacji monitoringu jakości powietrza zlokalizowanej $\mathrm{w}$ kanionie ulicznym aleja Krasińskiego w Krakowie w 2012 roku

Fig. 3. Comparison of the modelled results $\left(\mathrm{S}_{\mathrm{mod}}\right)$ and the concentration values $\left(\mathrm{S}_{\mathrm{obs}}\right)$ measured at the air quality monitoring station located in the Krasinski alley street canyon in Krakow in 2012

\subsection{Wpływ emisji z transportu drogowego na jakość powietrza}

Na rysunku 4 przedstawiono stopień oddziaływania emisji z transportu drogowego na jakość powietrza, wyrażony w postaci udziału procentowego stężeń powodowanych przez poruszające się pojazdy względem stężeń zmierzonych na stacji monitoringu jakości powietrza dla wybranych zanieczyszczeń gazowych 
i pyłowych. Przedstawione udziały procentowe (rys. 4) wskazują, że transport drogowy w dużym stopniu przyczynia się do występowania wysokich stężeń $\mathrm{NO}, \mathrm{NO}_{2}$ i $\mathrm{NO}_{\mathrm{x}} \mathrm{w}$ powietrzu kanionu alei Krasińskiego. Średnioroczny udział transportu drogowego w kształtowaniu poziomów stężeń $\mathrm{NO}_{2} \mathrm{w}$ kanionie alei Krasińskiego jest bardzo wysoki i wynosi $58 \%$, w okresie letnim $62 \%$ a w okresie zimowym $52 \%$. Udziały procentowe stężeń $\mathrm{NO}$ i $\mathrm{NO}_{x}$ przedstawiają podobne tendencje jednak charakteryzują się wyższymi wartościami. Biorąc pod uwagę fakt, że wyniki obliczeń stężeń $\mathrm{NO}$ i $\mathrm{NO}_{\mathrm{x}} \mathrm{w}$ powietrzu (tabela 1) wynikające $\mathrm{z}$ emisji z transportu drogowego mogą być niedoszacowane, realne oddziaływanie emisji $\mathrm{NO} \mathrm{i} \mathrm{NO}_{\mathrm{x}} \mathrm{z}$ transportu drogowego na jakość powietrza w analizowanym kanionie ulicznym jest proporcjonalnie większe.

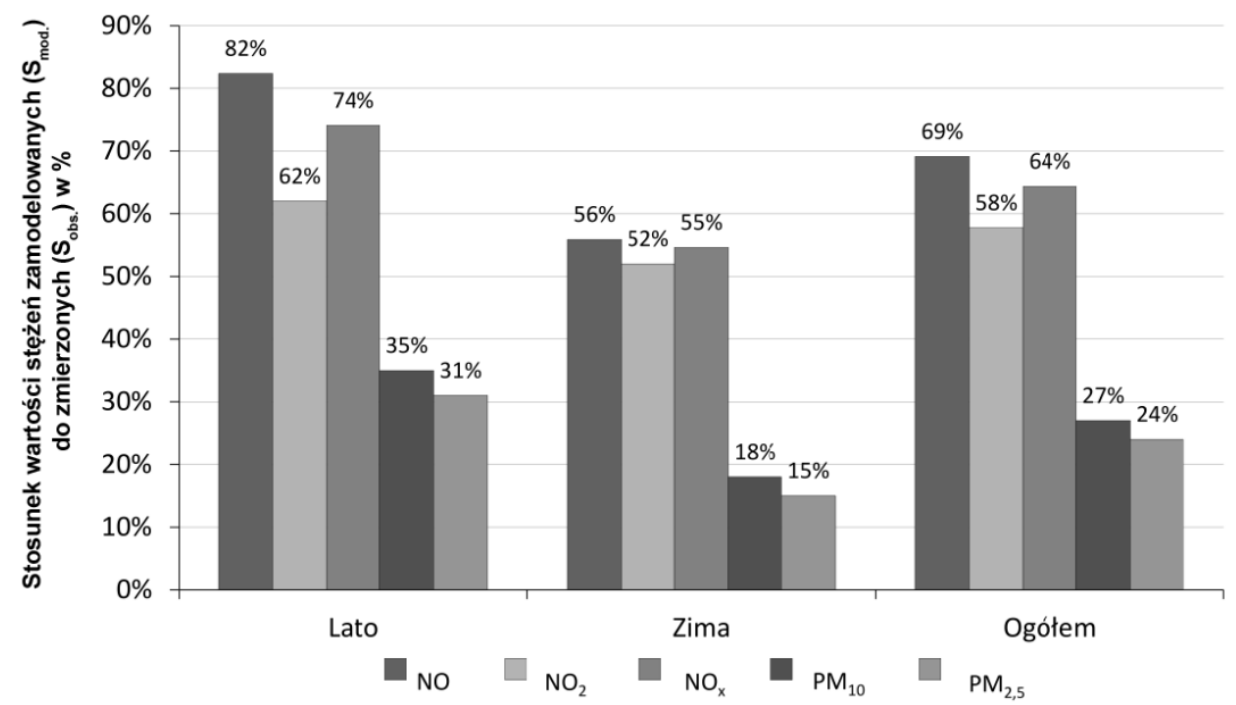

Rys. 4. Zestawienie procentowych udziałów zamodelowanych stężeń $\mathrm{NO}, \mathrm{NO}_{2}, \mathrm{NO}_{\mathrm{x}}, \mathrm{PM}_{10}$ i $\mathrm{PM}_{2,5}$ wynikających z emisji z transportu drogowego w odniesieniu do wartości stężeń zmierzonych na stacji monitoringu jakości powietrza zlokalizowanej w kanionie ulicznym alei Krasińskiego z podziałem na okres letni, zimowy i ogółem

Fig. 4. Percentage shares of modelled $\mathrm{NO}, \mathrm{NO}_{2}, \mathrm{NO}_{\mathrm{x}}, \mathrm{PM}_{10}$ and $\mathrm{PM}_{2.5}$ concentrations originating from the road transport emission in relation to the measured concentrations from the air quality monitoring station located in the Krasinski alley street canyon during summer, winter and total period

Emisja z silników pojazdów samochodowych w mniejszym stopniu kształtuje poziomy stężeń $\mathrm{PM}_{10}$ i $\mathrm{PM}_{2,5}$ w powietrzu atmosferycznym w porównaniu do tlenków azotu. Wyraźna jest natomiast różnica pomiędzy udziałami w okresie letnim i zimowym. Ta różnica wynika ze zwiększonej emisji pyłów z sektora komunalnego oraz przemysłowego, w tym głównie energetyki zawodowej 
w okresie zimowym. Podobny efekt zaobserwowano również w badaniach prowadzonych na terenie aglomeracji górnośląskiej [29, 30]. Autorzy tych prac stwierdzili również, że emisja cząstek stałych z innych źródeł niż komunikacyjne może przyczyniać się do maskowania oddziaływania $\mathrm{z}$ transportu drogowego. Istotne mogą być również efekty tworzenia się wtórnych zanieczyszczeń pyłowych z prekursorów nieorganicznych i organicznych. Udział transportu drogowego w kształtowaniu poziomu stężeń $\mathrm{PM}_{10}$ i $\mathrm{PM}_{2,5} \mathrm{~W}$ powietrzu może być jeszcze większy niż przedstawia to rysunek 4 . Przyjmując, zgodnie z wynikami badań [31], że udział pyłu wtórnego $\left(\mathrm{PM}_{2.5}\right)$ unoszonego $\mathrm{z}$ nawierzchni drogi na poziom stężenia sumarycznego powodowanego przez transport drogowy wynosi ok. 20-25\%, to w sytuacji, gdy w okresie letnim faktyczny udział transportu drogowego w kształtowaniu poziomu stężenia $\mathrm{PM}_{2,5} \mathrm{~W}$ powietrzu przekracza $40 \%$, wówczas ogólny udział pyłu unoszonego z drogi przekracza $30 \%$ sumarycznego stężenia powodowanego przez transport drogowy.

Na rysunku 5 przedstawiono procentowe wartości udziałów stężeń zamodelowanych w stosunku do stężeń zmierzonych dla okresu doby. Wartości te tylko w pewnym stopniu korelują $\mathrm{z}$ dobową zmiennością natężenia ruchu przedstawioną na rysunku 1 . W rzeczywistości nie występuje silna korelacja pomiędzy tymi parametrami, gdyż determinanty meteorologiczne są głównym czynnikiem kształtującym poziomy stężeń zanieczyszczeń w powietrzu. Należy podkreślić, że większość parametrów meteorologicznych również charakteryzuje się cyklicznością dobową i sezonową np.: prędkość wiatru, wysokość warstwy mieszania czy temperatura powietrza [5, 7]. Mierzone na pobliskiej stacji meteorologicznej (AGH) prędkości wiatru są z reguły większe w ciągu dnia niż w porze nocnej. Tendencja ta dotyczy także wysokości warstwy mieszania [6] oraz klas stabilności atmosferycznej. Parametry meteorologiczne odpowiadające niekorzystnym warunkom dyspersyjnym i minimalna emisja wynikająca $\mathrm{z}$ małego natężenia ruchu powodować może wyższe stężenia zanieczyszczeń w powietrzu niż miało by to miejsce przy korzystnych warunkach meteorologicznych i wysokiej emisji substancji do powietrza. Należy nadmienić, że zachodzące w atmosferze procesy transformacji zanieczyszczeń, szczególnie tlenków siarki i azotu do siarczanów i azotanów powodują w efekcie końcowym powstawanie wtórnych cząstek stałych. W zależności od dostępności reagentów (prekursorów tworzenia się aerozolu) i warunków atmosferycznych (szczególnie wilgotności i temperatury) wystąpić mogą w określonych porach doby wzrosty stężeń pyłów, wynikające z przemian chemicznych zachodzących w atmosferze [32, 33].

Efekt zmian udziału emisji z transportu drogowego w kształtowaniu poziomów stężeń zanieczyszczeń powietrza w kanionie ulicznym alei Krasińskiego przedstawiony na rysunku 5 wskazuje, że w godzinach popołudniowych stężenia $\mathrm{NO}_{2}$ i $\mathrm{PM}_{10}$ mogą być nawet odpowiednio w $80 \%$ i $40 \%$ determinowane przez emisję z transportu drogowego. Przedstawiona na rysunku 5 zależność wskazuje, że wzrost udziału stężeń pyłów pochodzących z transportu drogowego następuje w godzinach porannych i utrzymuje się do późnego popołudnia. Oznacza to, że 
w okresie wzmożonego ruchu pieszego następuje najsilniejsze oddziaływanie emisji z transportu drogowego na zdrowie ludzi. Dotychczasowe badania wskazują, że w tym okresie ma miejsce wyraźny wzrost liczby bardzo drobnych $(<100 \mathrm{~nm})$ cząstek w powietrzu, charakteryzujących się dużym, negatywnym wpływem na zdrowie ludzi [32-35].

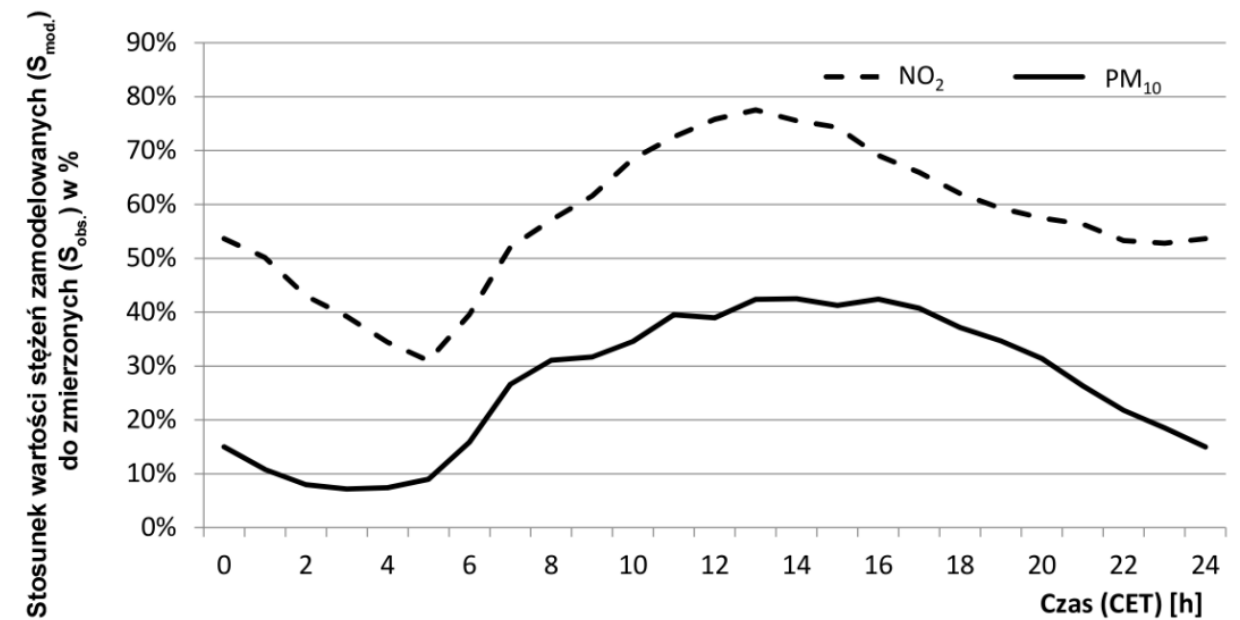

Rys. 5. Zestawienie procentowych udziałów zamodelowanych stężeń godzinowych $\mathrm{NO}_{2}$ i $\mathrm{PM}_{10}$ wynikających z emisji z transportu drogowego w odniesieniu do wartości stężeń godzinowych zmierzonych w cyklu dobowym na stacji monitoringu jakości powietrza zlokalizowanej w kanionie ulicznym alei Krasińskiego w 2012 r.

Fig. 5. Percentage shares of modelled hourly averaged $\mathrm{NO}_{2}$ and $\mathrm{PM}_{10}$ concentrations originating from the road transport in relation to hourly averaged concentrations measured in the daily cycles at the air quality monitoring station located in the Krasinski alley street canyon in 2012

\section{Podsumowanie}

Przedstawione w pracy wyniki badań modelowych oraz porównawczych wskazują, że stężenia zanieczyszczeń powietrza powodowane wyłącznie przez emisję z silników spalinowych pojazdów poruszających się w rejonie kanionu ulicznego alei Krasińskiego mogą prowadzić do występowania przekroczeń średniorocznego poziomu dopuszczalnego stężenia $\mathrm{NO}_{2}$ i nie są $\mathrm{w}$ istotny sposób odpowiedzialne za wysokie poziomy stężeń $\mathrm{w}$ powietrzu pyłów $\mathrm{PM}_{10}$ i $\mathrm{PM}_{2,5}$. Wydaje się, że na poziom stężeń pyłu $\mathrm{PM}_{10}$ i $\mathrm{PM}_{2,5} \mathrm{w}$ powietrzu kanionu ulicznego może w zdecydowanie większym stopniu wpływać emisja wtórna pyłu z dróg [32]. Emisja ta nie została jednak uwzględniona w obliczeniach, gdyż nie została zaimplementowana w oprogramowaniu WinOSPM, które służyło do oszacowania emisji z pojazdów samochodowych. Wyniki oceny modelu 
wykazały również, że emisja $\mathrm{NO}$ z transportu drogowego może być niedoszacowana. W przyszłości należy poświęcić tym zagadnieniom więcej uwagi poczynając od badań zmierzających do określenia ilości pyłu znajdującego się na drogach w celu oszacowania wtórnej emisji pyłu z dróg [36], a kończąc na lepszym rozpoznaniu struktury pojazdów poruszających się po nich.

Badania modelowe wykazały, że udział transportu drogowego (emisje z silników oraz ścierania opon, okładzin i nawierzchni jezdni) w kształtowaniu średnich stężeń zanieczyszczeń powietrza $\mathrm{w}$ kanionie ulicznym $\mathrm{w}$ odniesieniu do: $\mathrm{NO}_{2}, \mathrm{PM}_{10}$ i $\mathrm{PM}_{2.5}$ wynosi odpowiednio: 58, 27 i $24 \%$. Jak można zauważyć emisje z silników samochodowych powodują w głównej mierze wzrost stężenia $\mathrm{NO}_{2} \mathrm{w}$ powietrzu, natomiast w mniejszym stopniu wpływają na poziom stężenia pyłu $\mathrm{PM}_{10}$ i $\mathrm{PM}_{2,5}$. Jednak należy mieć na uwadze, że emisje z silników spalinowych są odpowiedzialne za emisję ultra drobnych cząstek pyłu - mniejszych od $100 \mathrm{~nm}$ [32-35], których wpływ na zdrowie ludzi jest największy w bezpośrednim sąsiedztwie drogi [37]. Wprowadzając działania naprawcze w zakresie poprawy jakości powietrza atmosferycznego w Krakowie ze względu na stężenia pyłów zawieszonych, należy mieć więc na uwadze fakt, że nie tylko poziom stężenia pyłu w powietrzu stanowi zagrożenie dla zdrowia ludzi lecz również: wielkość, kształt, właściwości fizykochemiczne pyłów oraz zawartość substancji kancerogennych zaadsorbowanych na ich powierzchni [34].

\section{Praca powstała w ramach badań statutowych AGH nr 11.11.150.008 i grantu dziekańskiego.}

\section{Literatura}

[1] Wojewódzki Inspektorat Ochrony Środowiska w Krakowie (WIOŚ).: Pięcioletnia ocena jakości powietrza pod kątem jego zanieczyszczenia: $\mathrm{SO}_{2}, \mathrm{NO}_{2}, \mathrm{NO}_{\mathrm{x}}, \mathrm{CO}$, benzenem, $\mathrm{O}_{3}$, pyłem $\mathrm{PM}_{10}$, pyłem $\mathrm{PM}_{2,5}$ oraz As, $\mathrm{Cd}, \mathrm{Ni}, \mathrm{Pb}$ i B(a)P w województwie małopolskim uwzględniająca wymogi dyrektyw: 2008/50/WE i 2004/107/WE oraz decyzji 201. Kraków 2014. http://www.krakow.pios.gov.pl/publikacje /2014/5letnia_ocena_jakosci_powietrza_2013.pdf \{dostęp: 20.04.2016 r.\}.

[2] Główny Inspektor Ochrony Środowiska (GIOŚ): Bank danych pomiarowych jakości powietrza, http://powietrze.gios.gov.pl/pjp/home \{dostęp: 10.04.2016 r. \}.

[3] European Environment Agency (EEA): Air quality in Europe - 2015 report, Luxembourg: Publications Office of the European Union 2015. http://www.eea.europa.eu/publications/air-quality-in-europe-2015 \{dostęp: 26.04.2016 r.\}.

[4] Lo K.W., Ngan K.: Characterising the pollutant ventilation characteristics of street canyons using the tracer age and age spectrum, Atmospheric Environment, vol. 122, 2015, pp. 611-621. 
[5] Oleniacz R., Bogacki M., Rzeszutek M., Kot A.: Meteorologiczne determinanty jakości powietrza w Krakowie, (w:) Ochrona powietrza w teorii i praktyce, praca zbiorowa pod red. J. Konieczyński, Instytut Podstaw Inżynierii Środowiska PAN, Zabrze 2014, s. 163-178.

[6] Wagner P., Schäfer K.: Influence of mixing layer height on air pollutant concentrations in an urban street canyon, Urban Climate, vol. XX, 2015, pp. 1-13, http://www.sciencedirect.com/science/article/pii/S2212095515300328 \{dostęp: 26.04.2016 r.\}.

[7] Elminir H.K.: Dependence of urban air pollutants on meteorology, Science of the Total Environment, vol. 350, 2005, pp. 225-37.

[8] Tong N.Y.O., Leung D.Y.C.: Effects of building aspect ratio, diurnal heating scenario, and wind speed on reactive pollutant dispersion in urban street canyons, Journal of Environmental Sciences (China), vol. 24, no. 12, 2012, pp. 2091-2103.

[9] Holmes N.S., Morawska L.: A review of dispersion modelling and its application to the dispersion of particles: An overview of different dispersion models available, Atmospheric Environment, vol. 40, 2006, pp. 5902-5928.

[10] Vardoulakis S., Fisher B.E., Pericleous K., Gonzalez-Flesca N.: Modelling air quality in street canyons: A review, Atmospheric Environment, vol. 37, 2003, pp. 155-182.

[11] Tominaga Y., Stathopoulos T.: CFD modeling of pollution dispersion in a street canyon: Comparison between LES and RANS, Journal of Wind Engineering and Industrial Aerodynamics, vol. 99, 2011, pp. 340-348.

[12] Murena F., Favale G., Vardoulakis S., Solazzo E.: Modelling dispersion of traffic pollution in a deep street canyon: Application of CFD and operational models, Atmospheric Environment, vol. 43, 2009, pp. 2303-2311.

[13] Rzeszutek M., Kasietczuk M., Bogacki M.: Impact assessment of road transport on air quality in the selected area of Krakow, Logistyka, nr 4, 2014, s. 4864-4873.

[14] Méline J., Wicherek S., Julien-Laferrière B., Oudinet J.: Assessment of exposure to air pollution from road traffic: use of air dispersion model CALINE4 at a fine scale in Cracow, Prace Geograficzne, vol. 127, 2011, pp. 87-113.

[15] Oudinet J.P., Méline J., Obtulowicz K., Wicherek S., Piotrowicz K., JulienLaferrière B.: Assessment of interactions between quality of urban landscape and human health, the case study in a Central European city, The Problems of Landscape Ecology, vol. 30, 2011, pp. 279-292.

[16] Benson P.E.: CALINE4-a Dispersion Model for Predicting Air Pollution Concentration Near Roadways, Report no. FHWA/CA/TL-84/15,California Department of Transportation, Sacramento 1989, http://www.dot.ca.gov/research/researchre ports/1981-1988/84-15.pdf \{dostęp: 26.04.2016 r. \}.

[17] Gualtieri G.: A street canyon model intercomparison in Florence, Italy, Water, Air, \& Soil Pollution, vol. 212, 2010, pp. 461-482.

[18] Heist D.K., Isakov V., Perry S.G., Snyder M.G., Venkatram A., Hood C., et al.: Estimating near-road pollutant dispersion: A model inter-comparison, Transportation Research Part D: Transport and Environment, vol. 25, 2013, pp. 93-105.

[19] Berkowicz R.: OSPM - a parameterised street pollution model, Environmental Monitoring and Assessment, vol. 65, 2000, pp. 323-31. 
[20] Berkowicz R., Ketzel M., Jensen S.S., Hvidberg M., Raaschou-Nielsen O.: Evaluation and application of OSPM for traffic pollution assessment for a large number of street locations, Environmental Modelling and Software, vol. 23, 2008, pp. 296-303.

[21] Ketzel M., Berkowicz R., Lohmeyer A.: Comparison of numerical street dispersion models with results from wind tunnel and field measurements, Environmental Modelling and Software, vol. 65, 2000, pp. 363-370.

[22] Elbir T., Kara M., Bayram A., Altiok H., Dumanoglu Y.: Comparison of predicted and observed PM10 concentrations in several urban street canyons Air Quality, Atmosphere and Health, vol. 4, 2011, pp. 121-131.

[23] Vardoulakis S., Valiantis M., Milner J., ApSimon H.: Operational air pollution modelling in the UK-Street canyon applications and challenges, Atmospheric Environment, vol. 41, 2007, pp. 4622-4637.

[24] Bogacki M, Kot A, Rzeszutek M. Model of averaging traffic flow variability profiles based on the examples of selected streets in Krakow, Logistyka, vol. 4 2015, pp. 8694-8702.

[25] Główny Urząd Statystyczny (GUS): Bank Danych Lokalnych, https://bdl.stat.gov.pl/BDL/start \{dostęp: 26.04.2016 r.\}.

[26] European Environment Agency (EEA). EMEP/EEA air pollutant emission inventory guidebook 2013, Technical guidance to prepare national emission inventories. Luxembourg: Publications Office of the European Union 2013, http://www.eea.europa.eu/publications/emep-eea-guidebook-2013 \{dostęp: 26.04.2016 r.\}.

[27] Scire J.S., Robe F.R., Fernau M.E., Yamartino RJ.: A user's guide for the CALMET meteorological model (Version 5). Earth Tech, Inc. Concord, MA 2000, http://www.src.com/calpuff/download/CALMET_UsersGuide.pdf \{dostęp: 26.04.2016 r.\}.

[28] Rozporządzenie Ministra Środowiska z dnia 24 sierpnia 2012 r. w sprawie poziomów niektórych substancji w powietrzu, Dz.U. 2013 poz. 1031.

[29] U.S. EPA: AP 42, Fifth Edition, Compilation of Air Pollutant Emission Factors. Section 13.2.1, Paved Roads. EPA contract No. 68-D0-0123, Work Assignment no. 44, 2011, https://www3.epa.gov/ttn/chief/ap42/ch13/final/c13s01.pdf \{dostęp: 26.04.2016 r.\}.

[30] Rogula-Kozłowska W., Rogula-Kopiec P., Klejnowski K., Błaszczyk J.: Wpływ emisji komunikacyjnej na stężenie dwóch form węgla i rozkład ich masy względem wielkości cząstek w aerozolu atmosferycznym obszaru miejskiego, Rocznik Ochrony Środowiska, vol. 15, 2013, pp. 1623-1644.

[31] Kozielska B., Rogula-Kozłowska W., Pastuszka J.S.: Wpływ ruchu drogowego na stężenia $\mathrm{PM}_{2,5}, \mathrm{PM}_{10}$ i WWA w warunkach wysokiej i niskiej emisji komunalnej, (w:) Polska Inżynieria Środowiska pięć lat po wstąpieniu do Unii Europejskiej, praca zbiorowa pod red. J. Ozonka, M. Pawłowskiej, Monografie Komitetu Inżynierii Środowiska PAN, vol. 58, tom 1, 2009, s. 129-37.

[32] Mancilla Y., Mendoza A.: A tunnel study to characterize PM2.5 emissions from gasoline-powered vehicles in Monterrey, Mexico, Atmospheric Environment, vol. 59, 2012, pp. 449-460. 
[33] Weber S., Kordowski K., Kuttler W.: Variability of particle number concentration and particle size dynamics in an urban street canyon under different meteorological conditions, Science of the Total Environment, vol. 449, 2013, pp. 102-114.

[34] Wehner B., Birmili W., Gnauk T., Wiedensohler A.: Particle number size distributions in a street canyon and their transformation into the urban background: Measurements and a simple model study, Atmospheric Environment, vol. 36, 2002, pp. 2215-2223.

[35] Chłopek Z, Suchocka K. Zagrożenia dla zdrowia ludzi i ich środowiska przez cząsteczki stałe w okolicach tras komunikacyjnych, Archiwum Motoryzacji, tom 63, nr 1, 2010, s. 109-129.

[36] Imhof D., Weingartner E., Prévôt A.S.H., Ordóñez C., Kurtenbach R., Wiesen P., et al.: Aerosol and NOx emission factors and submicron particle number size distributions in two road tunnels with different traffic regimes, Atmospheric Chemistry and Physics Discussions, vol. 5, 2005, pp. 5127-5166.

[37] Baldauf R., Thoma E., Hays M., Shores R., Kinsey J., Gullett B., et al.: Traffic and meteorological impacts on near-road air quality: summary of methods and trends from the Raleigh Near-Road Study, Journal of the Air \& Waste Management Association, vol. 58, no. 7, 2008, pp. 865-578.

\title{
AIR POLLUTANTS DISPERSION MODELLING IN THE STREET CANYON: CASE STUDY OF THE KRASINSKI ALLEY IN KRAKOW
}

\begin{abstract}
S u m m a r y
The paper presents an impact assessment of the road transport emission on air quality in the street canyon within the Krasinski alley in Krakow with particulate matter $\left(\mathrm{PM}_{10}\right.$ and $\left.\mathrm{PM}_{2,5}\right)$ and nitrogen dioxide $\left(\mathrm{NO}_{2}\right)$ concentration levels taken into consideration. The assessment was based on the results of mathematical modelling using the OSPM model (Operational Street Pollution Model). The emissions of air pollutants from road transport were estimated accordingly to the CORINAIR methodology developed by the European Environment Agency, For the calculation process the meteorological data were derived from the station located in the region of AGH University of Science and Technology in Krakow and the background pollution data were obtained from the air quality measurement station at the Bujaka street in Krakow. Additionally, the paper presents a comparison between modelling results and measured concentrations from air quality monitoring station located in the street canyon within the Krasinski alley. The results obtained confirmed a significant role of the road transport emission in air quality within the street canyon area and an association with the occurrence of excessive $\mathrm{NO}_{2}$ and particulate matter $\left(\mathrm{PM}_{10}\right.$ and $\mathrm{PM}_{2,5}$ ) concentrations in the air. It was found that the impact of road transport on the concentration levels of $\mathrm{NO}_{2}, \mathrm{PM}_{10}$ and $\mathrm{PM}_{2.5}$ in the air varies seasonally with the biggest influence observed in the summer. During this period, the road transport emission is shaping $\mathrm{NO}_{2}, \mathrm{PM}_{10}$ and $\mathrm{PM}_{2.5}$ concentration levels in the street canyon in 62,35 and $31 \%$, respectively.
\end{abstract}

Keywords: emission, road transport, air quality impact assessment, street canyon, air pollutant dispersion modelling, OSPM model 
DOI:10.7862/rb.2016.148

Przestano do redakcji: 01.05.2016 r.

Przyjęto do druku: 28.06.2016r. 